\title{
Article \\ Phenological Assessment for Agronomic Suitability of Some Agastache Species Based on Standardized BBCH Scale
}

\author{
Rodica Vârban ${ }^{1} \mathbb{D}$, Andreea Ona ${ }^{2, *(\mathbb{D})}$, Andrei Stoie ${ }^{1,3, *}$, Dan Vârban ${ }^{4}$ and Ioana Crișan ${ }^{1,3} \mathbb{D}$ \\ 1 Department of Botany, Faculty of Agriculture, University of Agricultural Sciences and Veterinary Medicine, \\ Calea Mănăștur Street No. 3-5, 400372 Cluj-Napoca, Romania; rodica.varban@usamvcluj.ro (R.V.); \\ ioana.crisan@usamvcluj.ro (I.C.) \\ 2 Department of Plant Breeding, Faculty of Agriculture, University of Agricultural Sciences and Veterinary \\ Medicine, Calea Mănăștur Street No. 3-5, 400372 Cluj-Napoca, Romania \\ 3 Agro-Botanical Garden (CLA), University of Agricultural Sciences and Veterinary Medicine, Calea Mănăștur \\ Street No. 3-5, 400372 Cluj-Napoca, Romania \\ 4 Department of Crop Technology, Faculty of Agriculture, University of Agricultural Sciences and Veterinary \\ Medicine, Calea Mănăștur Street No. 3-5, 400372 Cluj-Napoca, Romania; dan.varban@usamvcluj.ro \\ * Correspondence: andreea.ona@usamvcluj.ro (A.O.); andrei.stoie@usamvcluj.ro (A.S.)
}

Citation: Vârban, R.; Ona, A.; Stoie, A.; Vârban, D.; Crișan, I. Phenological Assessment for Agronomic Suitability of Some Agastache Species Based on Standardized BBCH Scale. Agronomy 2021, 11, 2280. https://doi.org/ 10.3390 /agronomy 11112280

Academic Editor: Emanuele Radicetti

Received: 24 September 2021

Accepted: 9 November 2021

Published: 11 November 2021

Publisher's Note: MDPI stays neutral with regard to jurisdictional claims in published maps and institutional affiliations.

Copyright: (c) 2021 by the authors. Licensee MDPI, Basel, Switzerland. This article is an open access article distributed under the terms and conditions of the Creative Commons Attribution (CC BY) license (https:// creativecommons.org/licenses/by/ $4.0 /)$.

\begin{abstract}
Increasing interest in medicinal plants encourages the growers to consider extending their range of cultivated species. Acclimatization and adaptation of species introduced for cultivation in new areas remain a challenge of modern agriculture. One of the first steps for optimizing the cultivation technology is determining the plant phenology in the local conditions. Therefore, the aim of this research was to provide a standardized phenology scale for Agastache sp. and to apply it in assessing the suitability for cultivation in a local environment of some valuable Agastache species: Agastache scrophulariifolia, Agastache rugosa, Agastache mexicana, Agastache foeniculum and Agastache rugosa 'After Eight'. During the vegetation period, nine growth stages were identified: germination/emergence, leaf development, formation of side shoots, stem elongation, inflorescence emergence, flowering, fruit development, fruit maturity, senescence and beginning of resting. Observations conducted over two years revealed that the vegetation period increased from $168.8 \pm 3.51$ days in the first year to $199.0 \pm 1.82$ days in the second year. In both vegetation periods, the flowering phenophase predominated, but the abundance of precipitations shortened the flowering duration in the second year. The duration of phenophases was highly influenced by growing degree days. Phenological assessment based on a standardized scale can be a useful tool for evaluating cultivation potential and the planning of technological resources.
\end{abstract}

Keywords: temperature; precipitations; acclimatization; growth stage; medicinal plants

\section{Introduction}

There is growing interest at the international level for aromatic and medicinal plants due to their wide range of applications. Increasing awareness among consumers on the health benefits associated with their use has increased the demand worldwide [1,2]. The largest share on the global market of botanicals belongs to herbal medicines (48\%) followed by supplements and functional foods (35\%) and then the cosmetics sector (17\%) [2]. In this context, there is an opportunity for the cultivation of medicinal plants. However, in order to maximize the market potential and to remain competitive, growers have to consider extending their range of cultivated species and prospecting for the potential of promising genotypes new to their area.

Agastache Clayton ex Gronovis is a promising genus from the family Lamiaceae [3] alongside other traditionally cultivated species such as: Mentha $\times$ piperita L., Lavandula angustifolia Mill., Melissa officinalis L., Rosmarinus officinalis L., Salvia officinalis L., Ocimum basilicum L. and Origanum vulgare L. [4,5]. Plants of this botanic family contain aromatic 
oils in all organs and these are valuable for the cosmetic and perfume industry, for the food industry as culinary herbs, and for the production of pharmaceuticals and pesticides [6].

The genus Agastache comprises 22 species [7], native to North America, China and Japan, where they grow in dry scrub and fields. There are crossings between several species resulting in a range of hybrid cultivars of varying heights and colors [8,9]. Plants of this genus are perennial herbs reaching more or less one meter in height. Leaf shape varies but prevailingly is ovate or deltoid-ovate with the margins crenate-serrate [3,8]. Flowers are small and arranged in verticillasters subtended by bracts. The fruits consist of four small nutlets, hairy at the apex [3,7]. The phytochemical profile of the genus Agastache is characterized by the presence of phenylpropanoids and terpenoids. The typical flavonoids are acacetin and glycoside-tilianin [10].

This genus is highly promising because of the wide range of utilization possibilities, given the diverse bioactivity $[8,10,11]$, their potential to be used in the food industry as spice, preservative $[12,13]$ or in drinks $[8,11]$. It can also be cultivated as ornamental $[10,12]$ or as a melliferous crop for obtaining honey with health-promoting properties [14-16]. These species can also represent a food source for wild bees and butterflies [17,18]. The ecology of the studied species of Agastache is synthesized in Table 1.

Table 1. Ecology of the Agastache sp. studied.

\begin{tabular}{|c|c|c|c|}
\hline Species & Origin & Native Range and Spread & Habitats and Requirements \\
\hline A. scrophulariifolia & $\begin{array}{l}\text { North America } \\
{[11,19]}\end{array}$ & $\begin{array}{l}\text { Native and abundant from New York-New } \\
\text { Jersey southward to North Carolina and } \\
\text { westward to Illinois, Iowa and Wisconsin. } \\
\text { Less frequent in Connecticut, New } \\
\text { Hampshire, Vermont, Nebraska, South } \\
\text { Dakota and Minnesota [3,20]. Reported as } \\
\text { disappeared from Kansas, Massachusetts, } \\
\text { Georgia and Ontario [19]. }\end{array}$ & $\begin{array}{l}\text { Easily out-competed by other } \\
\text { plants. In native regions, grows in } \\
\text { upland woods, rich woodland } \\
\text { borders, meadows or upper limits } \\
\text { of floodplains. Threatened by } \\
\text { habitat loss [21]. }\end{array}$ \\
\hline A. rugosa & Eastern Asia [3] & $\begin{array}{l}\text { Native to China and Japan [8], Korea [22], } \\
\text { East Siberia [23]. }\end{array}$ & $\begin{array}{l}\text { In native regions, grows in grassy } \\
\text { mountain valleys and by the } \\
\text { streams [23]. Prefers full sun and is } \\
\text { frost hardy. Grows in hardiness } \\
\text { zones 7-11 [8]. }\end{array}$ \\
\hline
\end{tabular}

Native to the region extending from

Zacatecas southwards to Puebla [3]. Spontaneous throughout the

A. mexicana Mexico [8] Neovolcanense Province of central Mexico particularly in region of the volcano Popocatepetl, in the Ozumba Municipality, State of Mexico (Edomex), and in the Milpa Alta County, Mexico City [24].

Native range spreads throughout the states Wisconsin, Minnesota, Iowa, North Dakota A. foeniculum North America [8] to Wyoming and Colorado. In Canada is found from Ontario to Alberta.

Naturalized in other regions of North

Prefers full sun and is frost hardy. Grows in hardiness zones 8-10 [8]. America as well [3,20].

Although medicinal properties of the plants from the genus Agastache have received attention and are relatively well-known, the cultivation technology requires optimization. Currently, for Agastache, the hindrances in enhancing and predicting crop performance parameters arise from the lack of clearly defined technological packages based on crop physiology and lack of detailed information on phenological stages of this species that could consolidate technological approaches [25]. 
Romania is situated within hardiness zone 6. This zone spreads throughout the Northern Hemisphere, making a U-shape curve across USA, continuing in Europe with Scandinavian shores at its northern tier and then cutting a path through much of Central and Eastern Europe and moving into Asia via the Caspian Sea. Here, the average low temperature ranges during winter between -18 and $-23^{\circ} \mathrm{C}$. Spring can be long and moist, arriving early and staying late. Autumn provides the last bursts of color before plants are shedding their leaves. It is considered a crossover zone and able to sustain a large array of plants of varying hardiness than most other zones [8]. From the genus Agastache, so far, Romania has only cultivated A. foeniculum [26,27]. Hence, the behavior of other species is unknown.

When new species are considered to be taken into cultivation, understating and determining the plant phenology is the first step towards establishing the cultivation technology and previsioning the potential of their successful cultivation.

The BBCH scale (Biologische Bundesanstalt, Bundessortenamt und CHemische Industrie) [28] is a useful standardized decimal system that codifies the growth stages of plants and provides a common terminology that facilitates international agrarian-scientific and interdisciplinary communication [29]. The BBCH scale define the phenological events of plants that are important from the agricultural point of view as well as essential for understanding their developmental biology and the critical stages of their life cycle [30]. This scale has become widely used in agronomic practice at identifying the optimal stages for the application of fertilizers or plant protection products as well as in plant breeding to define earliness and maturity in the relationship with sowing/planting dates [29]. Since the initial works as well as the $\mathrm{BBCH}$ monograph defines the phenological particularities for only a handful of cultivated species $[28,29]$, standardization of growth stages based on $\mathrm{BBCH}$ for other plant species completes the literature and provides the means for other researchers to express their results in comparable ways. Thus far, the international literature lacks a standardized phenological description for Agastache.

Information obtained following phenological observations allows the reliable selection of genotypes that can be cultivated in certain local agro-climatic conditions. These also facilitate a better management and planning of technological resources for the entire duration of the growth period (in regards to establishing a calendar of agricultural activities).

In this study, some Agastache species were assessed: three new species that have not yet been reportedly cultivated in local conditions (A. scrophulariifolia (Willd.) Kuntze, $A$. rugosa (Fisch. et C. A. Mey.) Kuntze, A. mexicana (Kunth) Lint et Epling), one cultivar ( $A$. rugosa 'After Eight') and one species that has been cultivated in local conditions before: $A$. foeniculum (Pursh) Kuntze.

The aim of this research was to provide a standardized phenology scale based on the $\mathrm{BBCH}$ scale for Agastache sp. and present a proof of concept by using this scale to assess comparatively the agronomic suitability of some Agastache species for the cultivation in the local conditions.

Monitoring and highlighting the growth stages particularities under field cultivation, based on a standardized assessment scale, are essential before establishing technological approaches for the given genotypes in local conditions. In addition, phenological studies in the context of climate change become valuable instruments for future alert systems and such results can be used for the identification of critical growth stages when plants require prompt interventions of growers due to the unpredictability of ecological factors. Because the $\mathrm{BBCH}$ scale provides a unitary criterion for delimiting vegetation phases, which allows a detailed follow-up of the phenological events, this approach becomes essential in assessing the behavior of species that have not yet been cultivated in local climatic conditions.

Three objectives were established:

- Identification, standardization and description of phenophases for Agastache sp. based on the BBCH scale;

- Validation (application) of the BBCH scale comparatively for some Agastache species; 
- Determination of the relationship between the main ecological factors and the phenology, for successful cultivation.

\section{Materials and Methods}

\subsection{Study Site}

The experimental field was located in the Agro-Botanical Garden of the University of Agricultural Sciences and Veterinary Medicine (UASVM) from Cluj-Napoca, Romania, between the years 2019 and 2020. The Agro-Botanical Garden is located at latitude $46^{\circ} 45^{\prime} 36^{\prime \prime}$ $\mathrm{N}$ and longitude $23^{\circ} 34^{\prime} 24^{\prime \prime}$ E, elevation 380-430 $\mathrm{m}$ [31] in the Transylvania region. The soil of the Agro-Botanical Garden is characterized by a loam-clay texture, eubasic (V 92), with a low humus content $(1.35 \%), \mathrm{pH} 6.72$, very well supplied with nitrogen $(0.461 \%)$ and potassium (312 ppm) and well supplied with phosphorus (68 ppm) [32].

The climate of Romania is transitional temperate-continental, but the Cluj-Napoca climate has an oceanic influence [33]. According to the Köppen-Geiger classification, ClujNapoca has a warm humid continental climate (Dfb) [34]. The average annual temperature in Cluj-Napoca is $8.1^{\circ} \mathrm{C}$ and average annual sum of precipitation is $635 \mathrm{~mm}$ [31].

Climatic conditions during the months when the observations were conducted in the field are presented in Figure 1.

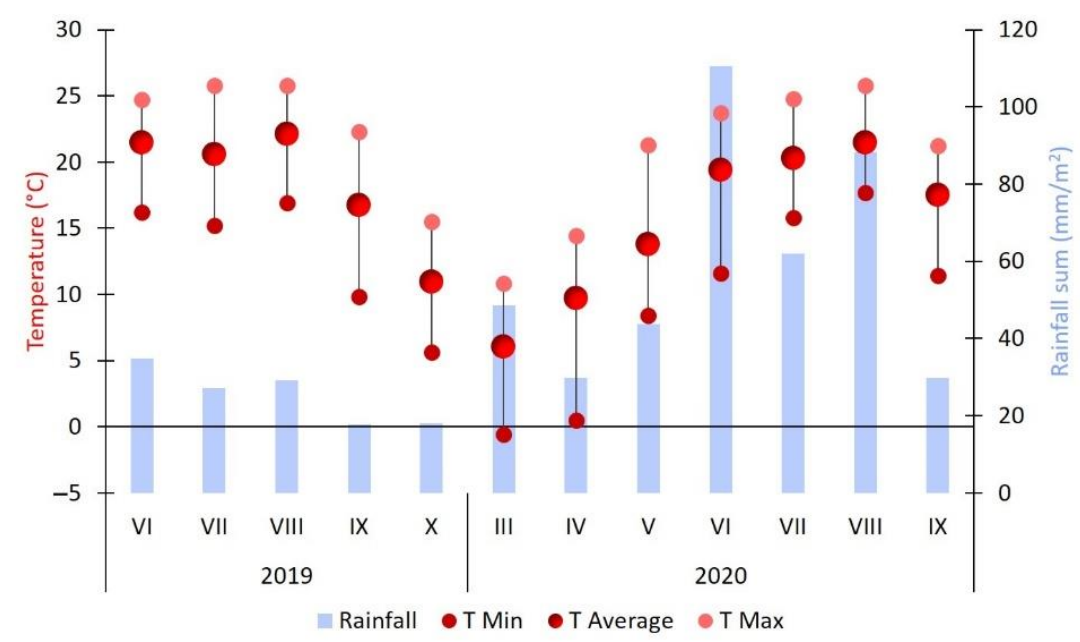

Figure 1. Weather conditions during the observation intervals in Cluj-Napoca, Romania; monthly mean temperature calculated based on daily average temperature; whiskers-minimum and maximum average daily temperature registered (data according to UASVM Cluj weather station).

During the summer months of 2020, the precipitations were more abundant compared to 2019, particularly in June and August. Average monthly temperatures in June and August were lower for 2020 compared to 2019 (Figure 1).

\subsection{Plant Material}

The biologic material used in this study was represented by five accessions of Agastache sp., as presented in Table 2.

Table 2. Agastache sp. accessions.

\begin{tabular}{ll}
\hline \multicolumn{1}{c}{ Accession } & IPEN $^{\mathbf{1}}$ Number \\
\hline Agastache scrophulariifolia (Willd.) Kuntze & XX-0-CLA-4155 \\
Agastache rugosa (Fisch. et C.A.Mey.) Kuntze & XX-0-CLA-4154 \\
Agastache rugosa 'After Eight' & XX-0-CLA-1950 \\
Agastache mexicana (Kunth) Lint et Epling & XX-0-CLA-4153 \\
Agastache foeniculum (Pursh) Kuntze & XX-0-CLA-4152 \\
\hline
\end{tabular}

${ }^{1}$ IPEN-international plant exchange network [31]. 
The seeds were obtained through an exchange system from Botanisches Institut und Botanischer Garten from Universität Gesamthochschule Essen, Germany.

There were four species and one cultivar studied. A. rugosa 'After Eight' is a creation of the breeder Brian Kabbes from the Netherlands [35].

Voucher specimens were deposited at the Agro-Botanical Garden Herbarium from UASVM Cluj-Napoca, voucher numbers 30078-30082.

Images with the studied species are presented in Figure 2.

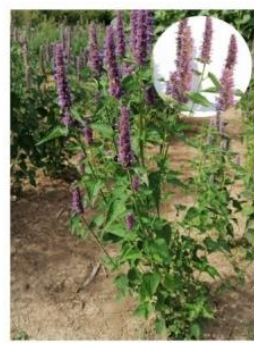

(a)

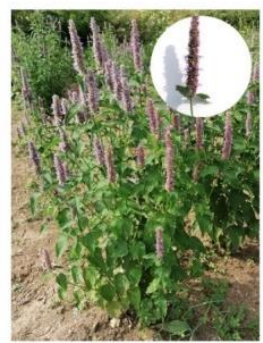

(b)

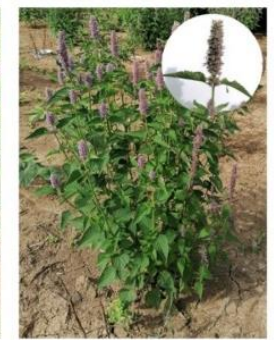

(c)

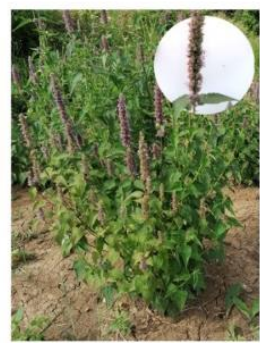

(d)

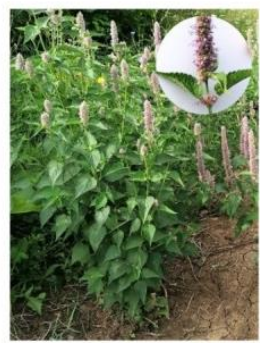

(e)

Figure 2. Aspects from the field with the Agastache species studied: (a) A. scrophulariifolia; (b) A. rugosa; (c) A. foeniculum; (d) A. rugosa 'After Eight'; (e) A. mexicana (original).

\subsection{Cultivation}

The crop in the first year was started from seedlings, obtained by sowing seeds in a heated greenhouse. The sowing was performed on 13 March 2019 and germination took 10 days. Pricking was performed when the plants had 4 fully developed leaves.

The experimental field crop was established in early summer (2 June 2019), as weather conditions due to excessive rainfall did not allow planting in May. Planting was performed at a distance of $70 \mathrm{~cm}$ between rows and $50 \mathrm{~cm}$ between plants on the row, recommended as optimal for the cultivation of $A$. foeniculum, in the conditions of Transylvania, Romania [26].

The experimental plot had about $1000 \mathrm{~m}^{2}$. At the planting time, the seedlings were vigorous, uniform, having 4 pairs of fully developed leaves and a well-developed root system. The survival rate was 100\%. Ten plants in four replicates were chosen as samples from each species/cultivar for detailed monitorization (a total of 200 plants $=10 \times 4 \times 5$ ), during a two-year interval (2019-2020). Plants were monitored by performing observations every two days.

The maintenance works carried out in the experimental field were manual and mechanical tillage. Watering was applied after planting, to ensure the establishment of the plants, and in moderate quantity for a few times only during periods of drought, to prevent wilting of the plants. The crop was kept free of weeds throughout the growing period.

\subsection{Observations}

For the phenological assessment, the following observations and determinations were conducted:

- Identification and description of principal and secondary growth stages;

- Duration of each phenophase (in number of days and as percentage);

- $\quad$ Growing degree days (GDD) per phenophase and entire vegetation period;

- Sum of precipitations accumulated per phenophase and entire vegetation period.

Growing degree days and precipitations were based on the data registered by the weather station from the campus of UASVM Cluj-Napoca, near the experimental field.

Identification and standardization of phenological stages were conducted by following and adapting the BBCH scale [28].

Duration of each phenophase was expressed in number of days. Then, the percentage of each phenophase from the duration of the entire growth period was calculated. 
Growing degree days for each phenophase and for the entire growth period was determined according to the Romanian agronomic literature $[5,36]$ by applying the Formula $(1)$ :

$$
B A T=\Sigma(T e f-T b)
$$

BAT (Biologically Active Temperatures) synonym with UTU (Useful Thermal Units) or GDD (Growing Degree Days) [37] were calculated based on Tef = effective temperature, expressed as average daily temperature (averaged between maximum daily temperature and minimum daily temperature) and $T b=$ base temperature or biological threshold $\left(\mathrm{Tb}<10^{\circ} \mathrm{C}\right)[5,36]$. For most field crops in Romania, the base temperature is considered $10{ }^{\circ} \mathrm{C}[5,38]$.

Considering that the Agastache species studied originate from North America and Asia, which have similar hardiness zones to the one from Romania, this base temperature was considered adequate.

The sum of precipitations (or rainfall regime) per phenophase was calculated by summing the precipitations registered during the days corresponding to that given phenophase [5].

\subsection{Statistical Analysis}

Statistical analysis was conducted in order to explore differences between phenophases and the relationships between environmental factors and phenological parameters in a comparative way.

Based on the observations and determinations, the descriptive statistics employed determined:

- The descriptive statistics (average, standard error, range of variability) using XLSTAT software [39].

- Scatterplot matrix with Pearson correlations for environmental and phenological variables using Origin software [40].

- Linear fitting for the duration of phenophase and its dependency on temperature and, respectively, precipitations using Origin software [40].

\section{Results}

\subsection{Identification of Growth Stages}

Based on the observation of the four Agastache species studied, we identified a succession of nine principal growth stages in the conditions of Cluj-Napoca Romania, as part of the growth period. The stages were defined following the $\mathrm{BBCH}$ scale and adapted accordingly with the particularities of these species in the local conditions.

\subsubsection{Principal Growth Stage 0: Germination/Emergence}

Succession of secondary stages within this principal growth stage slightly differs in the first and subsequent year (Table 3). In the first year (2019), the seeds (stage 00) were sown in the substrate (eutrophic peat) directly in the alveolar trays in greenhouse conditions. Sprouting of seeds lasted about 5 days (stage 03). After about 3 days, the embryo root was visible (stage 05). After 10 days the cotyledonal leaves appeared (stage 09). The studied accessions displayed a similar germination time. Because this phenophase is essential for the success of the culture, it requires special attention. In 2020, plants were already established in the field outdoors and the emergence of plants took place in the middle of March. Plants emerged from the renewal buds at the base of the remaining stems from the previous year, according to hemicryptophyte life-form. At first, the plants formed roots on the underground organs of the previous year (stage 05), then formed a rosette of leaves on the soil surface (stage 08), which at first had a purple hue. New shoots (stage 09) appeared from vegetative buds from the base of stems of the previous year. 
Table 3. Description of the phenological growth stages of Agastache, according to the BBCH scale.

\begin{tabular}{|c|c|c|}
\hline Principal Growth Stage & Description & $\begin{array}{c}\text { Secondary Growth } \\
\text { Stage }\end{array}$ \\
\hline \multirow{6}{*}{0 Germination/emergence } & Dry seed & 00 \\
\hline & Seed imbibition complete & 03 \\
\hline & Radicle emerged from seed/Perennating organs forming roots & 05 \\
\hline & Hypocotyl with cotyledons breaking through seed coat/new shoot & \\
\hline & growing towards soil surface & 08 \\
\hline & Emergence: cotyledons break through soil surface/new shoots emerge & 09 \\
\hline \multirow{6}{*}{1 Leaf development } & First leaves separated & 10 \\
\hline & First leaf pair (two leaves) unfolded & 11 \\
\hline & 2 leaf pairs (four leaves) unfolded & 12 \\
\hline & 3 leaf pairs (six leaf) unfolded & 13 \\
\hline & Stage continuous till ... & $1 n$ \\
\hline & 9 leaf pairs unfolded & 19 \\
\hline \multirow{5}{*}{2 Formation of side shoots } & First side shoot visible & 21 \\
\hline & 2 side shoots visible & 22 \\
\hline & 3 side shoots visible & 23 \\
\hline & Stage continuous till & $2 n$ \\
\hline & End of side shoot appearance: 9 or more shoots visible & 29 \\
\hline \multirow{5}{*}{3 Stem elongation } & Shoot development & 31 \\
\hline & Stem has two internodes & 32 \\
\hline & Stem has three internodes & 33 \\
\hline & Stages continuous till & $3 n$ \\
\hline & 9 or more internodes detectable & 39 \\
\hline \multicolumn{3}{|c|}{4 Development of harvestable vegetative plant parts or vegetatively propagated organs/booting (main shoot)—omitted } \\
\hline \multirow{3}{*}{5 Inflorescence emergence } & Beginning of verticillaster emergence & 50 \\
\hline & Verticillaster clearly separated (final total size) & 55 \\
\hline & Flowers visible in the inflorescence & 59 \\
\hline \multirow{3}{*}{6 Flowering } & Beginning of flowering: $10 \%$ of flowers open & 61 \\
\hline & Full flowering: $50 \%$ of flowers open, first petals may have fallen & 65 \\
\hline & Flowering ending: majority of petals fallen or dry; fruit set visible & 69 \\
\hline \multirow{3}{*}{7 Fruit development } & The fruits set at the base of the flowers in the inflorescence & 71 \\
\hline & $50 \%$ of fruits have the characteristic size and color & 75 \\
\hline & The fruits have a normal consistency and size & 79 \\
\hline \multirow{3}{*}{8 Fruit maturity } & Beginning of ripening or fruit coloration & 81 \\
\hline & Advanced stage of fruit coloration and ripening & 85 \\
\hline & Physiological maturity; dispersal begins & 89 \\
\hline \multirow{4}{*}{$\begin{array}{c}9 \text { Senescence, beginning } \\
\text { of resting }\end{array}$} & Foliage starts changing color & 91 \\
\hline & $50 \%$ of leaves fallen & 95 \\
\hline & Leaves fallen & 97 \\
\hline & Fruits dispersal continues, onset of winter resting & 99 \\
\hline
\end{tabular}

\subsubsection{Leaf Development}

In the species from genus Agastache, the leaves appear in pairs on shoots, decussate. In the first year, this phenophase begins with the development of the first cotyledonal leaves (stage 10). It is a phenophase difficult to delimit because it is overlapped with other phenophases or other secondary growth phases. Because the species from this study form a large number of shoots and the stem is branching, the formation and development of leaves can continue on the plant (stage 19). The phenophase was considered completed when the branching and formation of lateral shoots began (stage 2). In the first and second experimental years, plants had on average similar duration in days, but the range was larger for the second year (Table 4). 
Table 4. Descriptive statistics of Agastache sp. phenophases in Cluj-Napoca.

\begin{tabular}{|c|c|c|c|c|c|c|c|c|c|c|c|}
\hline & \multirow{2}{*}{$\begin{array}{l}\text { Parameters }{ }^{1} \\
\text { BBCH Stage }\end{array}$} & \multicolumn{9}{|c|}{ Phenophase (Number of Days) } & \multirow{2}{*}{ Vegetation Period } \\
\hline & & 0 & 1 & 2 & 3 & 5 & 6 & 7 & 8 & 9 & \\
\hline \multirow{3}{*}{2019} & Mean & 10 & 22.6 & 12.4 & 7.6 & 5.4 & 77 & 4.6 & 13 & 16.2 & 168.8 \\
\hline & $\pm S E$ & 0 & 1.6 & 3.03 & 1.75 & 0.68 & 4.57 & 0.87 & 1.52 & 2.44 & 3.51 \\
\hline & Range & 0 & 7 & 15 & 10 & 4 & 25 & 5 & 9 & 15 & 20 \\
\hline \multirow{3}{*}{2020} & Mean & 11.6 & 23 & 27 & 11.6 & 5.6 & 52.6 & 15.8 & 35.6 & 16.2 & 199 \\
\hline & $\pm \mathrm{SE}$ & 0.51 & 1.79 & 1.3 & 0.4 & 0.81 & 2.04 & 1.5 & 3.19 & 1.85 & 1.82 \\
\hline & Range & 3 & 10 & 7 & 2 & 4 & 10 & 9 & 18 & 10 & 10 \\
\hline
\end{tabular}

${ }^{1}$ Phenophase $\mathrm{BBCH}$ stages (1-9); $\pm \mathrm{SE}$ (standard error of mean); range $\left(\mathrm{x}_{\max }-\mathrm{x}_{\min }\right)$.

\subsubsection{Formation of Side Shoots}

This phenophase debuts with the formation of side shoots and branching of the stem (stage 21). In the first vegetative year, this phenophase started in the middle of June (15 June-1 July 2019) but much earlier in the second year (28 March-1 May 2020). Agastache species branch strongly and form a large number of side shoots, which is important for biomass production. The lateral shoots appear two each, from the axillary buds of the main shoots. Their number is variable, depending on the size of the plants in addition to other possible factors, but these ensure a high biomass production (stage 29). This phase lasted longer in the second year than in the first year (Table 4).

\subsubsection{Stem Elongation}

The first-year plants form a main stem that continues its growth (stage 31) until the appearance of the inflorescence. It was observed that in the first year when the crop was established by seedling, the stem had a shorter growth period. By comparison, in the second year, this phenophase lasted longer (Table 4). Starting with the second year, several stems appear on each plant from shoots that arise from the base of the main stem of the previous year, without necessarily differentiating a main stem-a fact noted by other authors as well [41].

Because the growth stage of harvestable vegetative parts or vegetative propagated organs (principal stage 4 ) is not a characteristic of this species, it was omitted.

The vegetative growth stages of Agastache are illustrated in Figure 3.

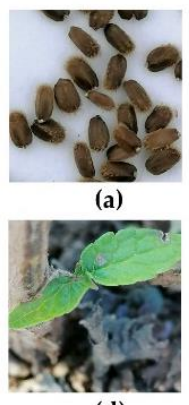

(d)

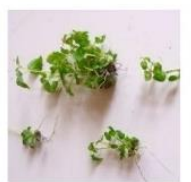

(b)

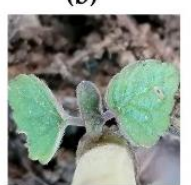

(e)

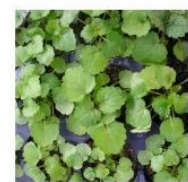

(c)

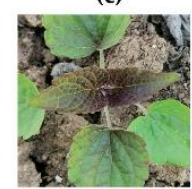

(f)

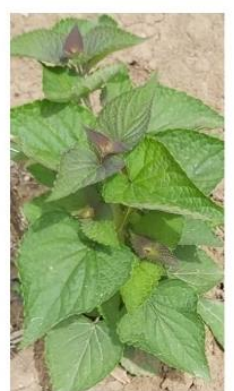

(g)

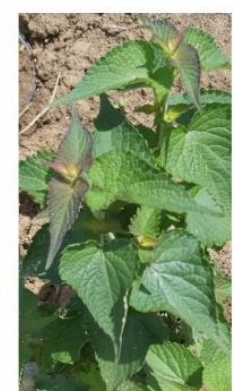

(h)

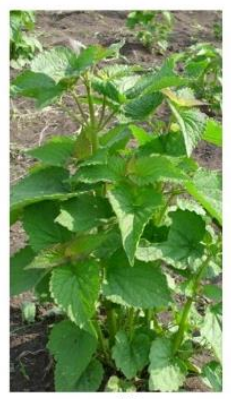

(i)

Figure 3. Vegetative growth stages of Agastache species studied according to BBCH scale; in the first year: (a) stage 00, (b) stage 09, (c) stage 12; in the second year: (d) stage 08, (e) stage 09, (f) stage 13; stages common in both years (g) stage 24, (h) stage 29, (i) stage 35; (original).

\subsubsection{Inflorescence Emergence}

Inflorescence emergence was a short phase, both in the first and in the second experimental year, after which the plants quickly passed into the next phenophase (Table 4). This phenophase began with the appearance of the first verticillaster in the inflorescence (stage 51), with two incompletely developed leaves formed at the base. The inflorescence at the beginning had small size $(1-2 \mathrm{~cm})$ but continued to develop by forming new 
verticillasters located at the top of the inflorescence (racemose inflorescence). Next, the verticillasters became fully visible (stage 55). This phenophase ended when flowers with a visible corolla appeared at the base of the inflorescence (stage 59). Inflorescence emergence partially overlaps with the main stages 1, 2 and 3, when both shoots and leaves from the younger shoots continue to grow and develop.

\subsubsection{Flowering}

This is the phenophase with the longest duration from the growing period in all the studied species. Blooming of the flowers started with the verticillaster situated at the base of the inflorescence (stage 61) and continued towards the top. While the blooming of flowers in the inflorescence progressed towards the top, the fruit setting starts at the base of the inflorescence (stage 69). Although this phase lasted longer in the first year compared to the second year, it also had a larger range (Table 4). This phenophase debuted at the end of June in the first year and beginning of summer in the second year.

The long period of flowering phenophase for Agastache species is largely influenced by the high number of inflorescences that appear on the lateral shoots, as well as their successive flowering. The fact that this phenophase takes place over a longer period of time is beneficial in order to better capture and manage the optimal time of harvest for medicinal purposes, while increasing the melliferous and decorative value of these species. Flowering (stage 6) in the first year lasted from the end of June until the middle of September, and after about a week, the fruiting began (stage 7). In the second year, flowering debuted a month earlier.

\subsubsection{Fruit Development}

This principal phenophase (stage 7) captures the fruit set and growth. The fruit set in the verticillaster at the base of flowers (stage 71) overlaps with the flowering stage (65) or the end of flowering (stage 69). Phenophase is considered complete when all fruits have the specific consistency and size indicated by the hard epicarp, while their size reaches about $1.5 \times 0.9 \mathrm{~mm}$ (stage 79). The development of fruits took place in the second half of September in 2019 having a short duration, while in the second year (2020) it took place during August and had a longer duration (Table 4).

The reproductive growth stages of Agastache are presented in Figure 4.

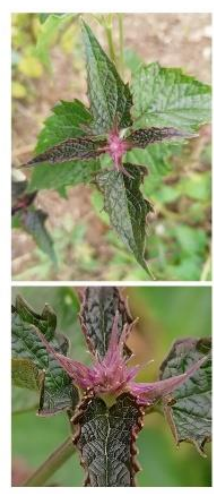

(a)

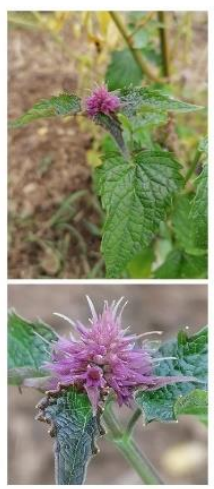

(b)

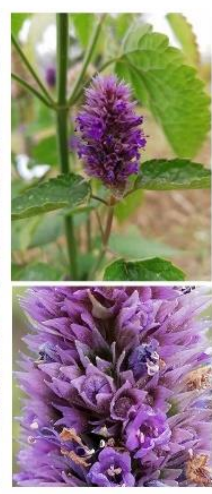

(c)

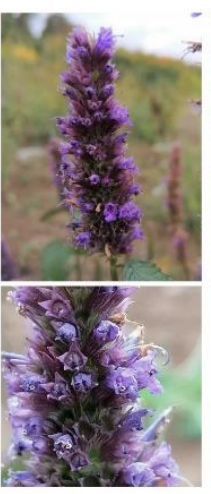

(d)

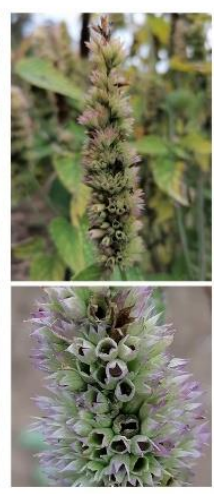

(e)

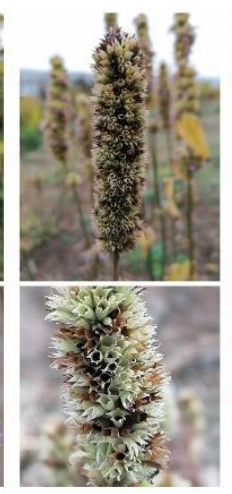

(f)

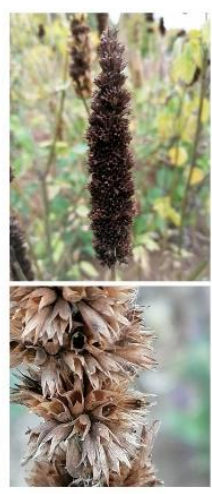

(g)

Figure 4. Reproductive growth stages of the Agastache species studied according to the BBCH scale: (a) stage 50; (b) stage 55; (c) stage 61; (d) stage 65; (e) stage 69; (f) stage 79; (g) stage 89; images from the second row are details (original).

\subsubsection{Fruit Maturity}

Maturity of the fruits was marked by the change in consistency and color (stage 81) and ended with their physiological maturity, after which the dispersal of the fruits began (stage 89). In the second year, the duration of this stage was more than double compared to the first year (Table 4). 


\subsubsection{Senescence/Beginning of Resting}

This stage marks the end of the vegetation period. This phenological stage begins with the yellowing of the basal leaves (stage 91), and next, the inflorescences turn brown (Figure 4). This stage ends when most fruits are being dispersed (stage 99), which occurs concomitantly with the wilting of the aboveground plant parts. For a while, the stems and shoots can remain green even after the leaves fall. Senescence had a similar duration in the two experimental years (Table 4). In the first year, it occurred in October, but in the second year, the senescence took place between the middle of September until the beginning of October. After this stage, the plants enter a resting state until the following spring. Since there were no plant losses between the two years and all plants overwintered successfully, it was deduced that all four species are hardy in the local climate.

Based on the observations of the four Agastache species in local conditions, it was determined that within the life cycle, the succession of vegetative and reproductive phenophases comprising the growth period occur between spring and autumn (Figure 5).

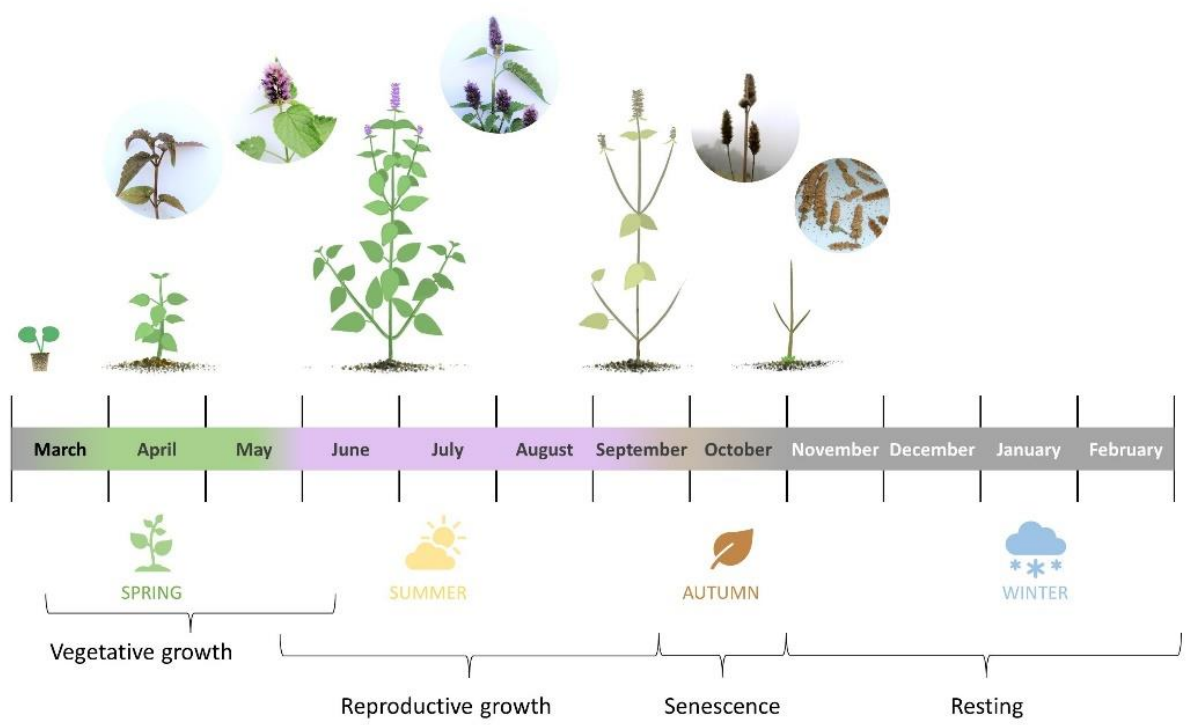

Figure 5. Main phenophases and life cycle of Agastache in Cluj-Napoca, Romania (original).

\subsection{Comparative Application of BBCH Scale for the Studied Species}

Although phenological observations conducted on the four species of Agastache allowed a standardized description based on the $\mathrm{BBCH}$ scale, some differences between species were noted regarding the date of debut, ending and duration of some growth stages.

The duration of first principal growth phenophase (stage 0) was somewhat similar across species and between the two years (Table 5 ). The tardiest species in the first year was A. foeniculum. It was noted that in the second year, A. rugosa, A. mexicana and A. foeniculum entered the vegetative period in the middle of March (2020), followed a few days later by A. rugosa 'After Eight'. From the studied species, A. scrophulariifolia was the last to enter the vegetative period in the second year (towards the end of March).

The shortest period of leaf development (stage 1) was recorded in the A. scrophulariifolia in the second year, and the longest in A. mexicana in the first year. For three out of four species, this growth stage lasted at least 20 or more days in both years (Table 4). 
Table 5. Duration (number of days) of growth stages of Agastache in Cluj-Napoca conditions.

\begin{tabular}{|c|c|c|c|c|c|c|c|c|c|c|}
\hline \multirow[t]{2}{*}{ Phenophase } & \multicolumn{2}{|c|}{ A. scrophulariifolia } & \multicolumn{2}{|c|}{ A. rugosa } & \multicolumn{2}{|c|}{$\begin{array}{c}\text { A. rugosa } \\
\text { 'After Eight' }\end{array}$} & \multicolumn{2}{|c|}{ A. mexicana } & \multicolumn{2}{|c|}{ A. foeniculum } \\
\hline & 2019 & 2020 & 2019 & 2020 & 2019 & 2020 & 2019 & 2020 & 2019 & 2020 \\
\hline $\begin{array}{c}0 \text { Germina- } \\
\text { tion/emergence }\end{array}$ & 10 & 10 & 10 & 12 & 10 & 11 & 10 & 12 & 10 & 13 \\
\hline 1 Leaf development & 20 & 16 & 20 & 24 & 20 & 24 & 27 & 26 & 26 & 25 \\
\hline $\begin{array}{l}2 \text { Formation of side } \\
\text { shoots }\end{array}$ & 7 & 28 & 9 & 27 & 7 & 22 & 17 & 29 & 22 & 29 \\
\hline 3 Stem elongation & 6 & 13 & 3 & 12 & 10 & 11 & 6 & 11 & 13 & 11 \\
\hline $\begin{array}{l}5 \text { Inflorescence } \\
\text { emergence }\end{array}$ & 5 & 8 & 6 & 7 & 3 & 5 & 6 & 4 & 7 & 4 \\
\hline 6 Flowering & 79 & 57 & 85 & 49 & 87 & 53 & 72 & 47 & 62 & 57 \\
\hline $\begin{array}{c}7 \text { Fruit } \\
\text { development }\end{array}$ & 6 & 16 & 2 & 12 & 4 & 14 & 4 & 21 & 7 & 16 \\
\hline 8 Fruit maturity & 12 & 39 & 13 & 43 & 8 & 39 & 15 & 32 & 17 & 25 \\
\hline $\begin{array}{l}9 \text { Senescence/ } \\
\text { beginning of resting }\end{array}$ & 15 & 10 & 25 & 20 & 15 & 18 & 10 & 14 & 16 & 19 \\
\hline $\begin{array}{l}\text { Number vegetation } \\
\text { days }\end{array}$ & 160 & 197 & 173 & 206 & 164 & 197 & 167 & 196 & 180 & 199 \\
\hline $\operatorname{GDD}\left({ }^{\circ} \mathrm{C}\right)$ & 2610.5 & 3117.4 & 2674.4 & 3151.4 & 2589.2 & 2997.2 & 2668.8 & 2978.5 & 2675.6 & 2997.6 \\
\hline Rainfall sum (mm) & 130.14 & 473.24 & 143.35 & 455.75 & 159.84 & 413.57 & 180.43 & 351.32 & 183.74 & 393.26 \\
\hline
\end{tabular}

In the first year, the plants elongated and branched during June (stages 2, 3). Formation of side shoots (stage 2) had a short duration in 2019 for the species $A$. scrophulariifolia and A. rugosa 'After Eight', but longest for A. mexicana and A. foeniculum. In 2020, in all species this principal stage (stage 2) lasted over 20 days, with the longest duration among species found in A. scrophulariifolia and A. rugosa (Table 5). Stem elongation (stage 3) varied both between species and years, and exceeded 10 days in all species in the second year (Table 5).

Both in the first and second years, the smallest share from the growing period corresponded to inflorescence emergence (stage 05), with the exception of A. mexicana and A. rugosa in the first year (Figure 6).

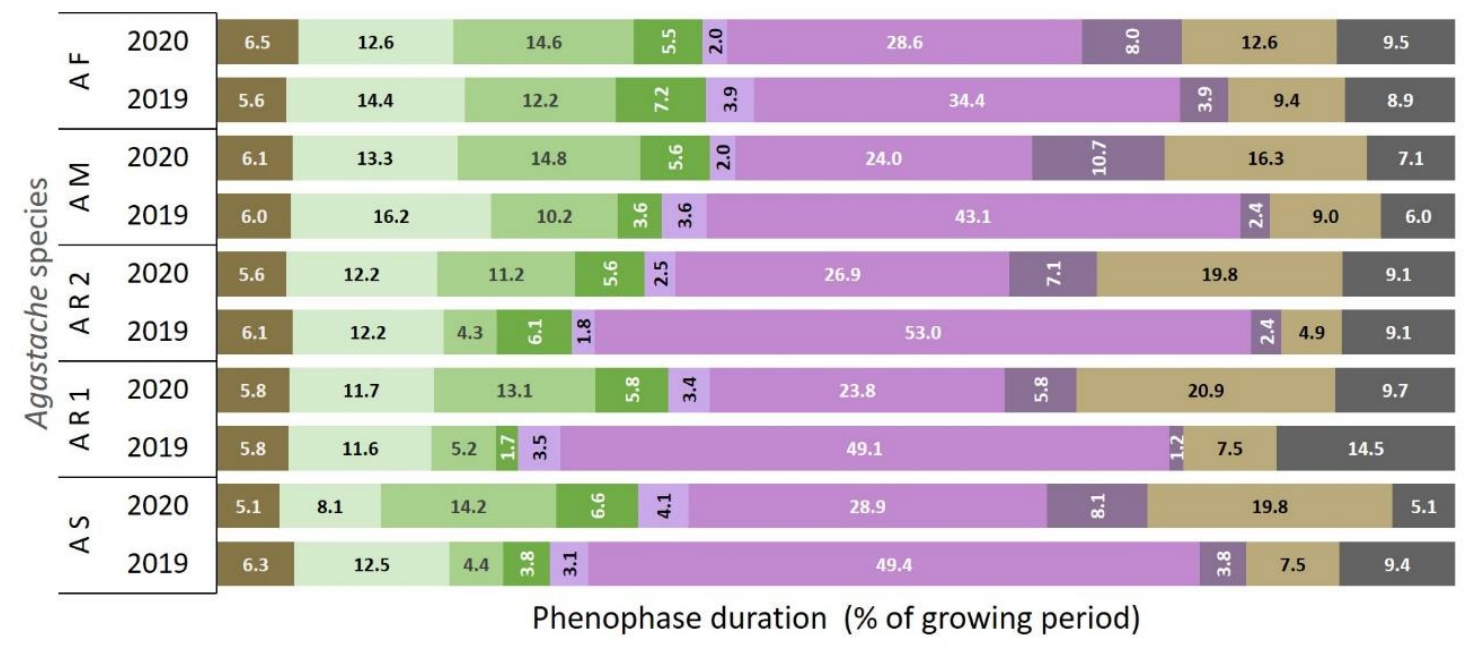

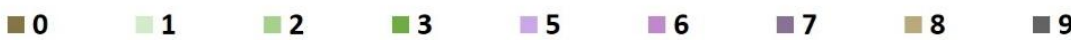

Figure 6. Comparison of the phenophase duration (\%) from the growing period of Agastache: AF-A. foeniculum, AMA. mexicana, AR2-A. rugosa 'After Eight', AR1-A. rugosa, AS-A. scrophulariifolia. 
The duration of flowering (stage 6) ranged between species, both in the first and second year. In 2019, the shortest duration was recorded by A. foeniculum. Both A. rugosa as well as A. rugosa 'After Eight' had the longest flowering duration, exceeding 80 days in the first year. In the second year, each species registered a shortening of flowering duration compared to the previous year. The shortest duration of less than 50 days was registered by A. rugosa followed by A. scrophulariifolia in 2020 (Table 5).

The dominant phenophase of the growing period was by far the flowering (stage 6) for all Agastache species having a share between 34.44 and 53.05\% from the first vegetation period and about 25\% from the second one (Table S3). The flowering share from the growing period was lower in the second year because the vegetation period had overall a much longer duration (Figure 6).

The phenophases 7 and 8 describe together the changes that fruits have to undergo from fruit set, fruit growth, maturation until ripening. For three of the species, these two phases together lasted less than 20 days in the first year, while in the second year exceeded 50 days in duration. The exception was A. foeniculum in both experimental years (Table 5). These stages are influenced by successive formation of inflorescences on the side shoots and their flowering.

Onset of senescence represented less than 10\% from the vegetation period in 2019 (with one exception) and for all species in 2020 (Figure 6). Senescence took place slowest for A. rugosa both in the first and second year compared to the other species, with a duration of $\geq 20$ days (Table 5), this prolonged the vegetation period to over 200 days (Table 5).

Based on the data from the two experimental years, one can conclude that there was an increase in the duration of the vegetation period in the second year, due to an increase in length of some phenophases, except the flowering (Table 5). Differences between the two experimental years are reflected in the average duration of phenophases in the species studied, more obvious for the growth phenophases 2, 3, 6, 7 and 8 (Table 5, Figure 6).

\subsection{Relationship with Climatic Factors}

The relationship between phenophases and the main climatic factors poses the importance for successful cultivation. This is because their variation in the case of critical phenophases is expected to be connected with the interventions required from growers in order to mitigate their potential negative effects.

Although the sum of precipitations per phenophase was less in 2019, after planting, a fast development of plants and a flowering period that lasted longer than in the second year (2020) was observed. This could be due to climatic conditions from the year 2019 that caused a shortening and acceleration of the succession of some vegetative stages (such as formation of side shoots in all species and stem elongation in three out of four species) and then prolonging the flowering.

The date of debut of all phenophases occurred earlier in the second year (2020) compared to the first, but their duration was longer in most. Compared to 2019, the growth phenophase 0 (emergence) and phenophase 1 (leaf development) took place during MarchApril, when there were lower temperatures, with a daily average below $10{ }^{\circ} \mathrm{C}$.

Although the inflorescences emerged (stage 05) earlier in 2020 than in 2019, the flowering period lasted less than in the previous year, being shortened by the abundant precipitations from this period (Table S2). The recorded temperatures of 2020 had lower values at the beginning of the vegetative period until the flowering period (stage 6) compared to 2019, but towards the end of the vegetation period, the recorded temperatures were higher in 2020 (Figure 7, Table S1). The trend for the GDD per phenophase remained the same between the first and the second year: highest for flowering, which also had the longest duration, and followed by fruit maturity (Figure 7). 


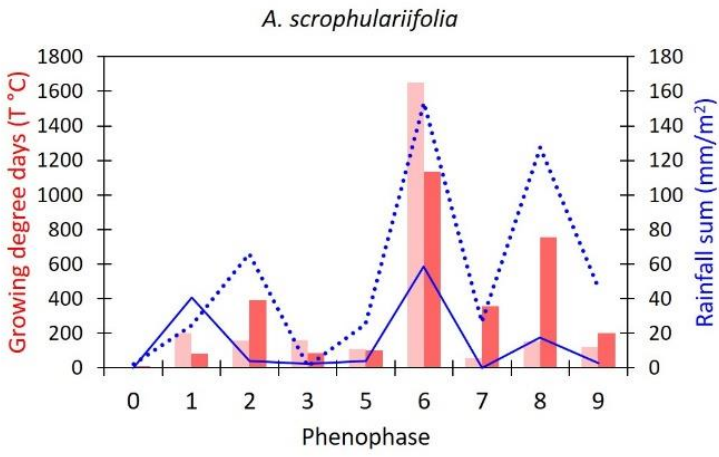

Growing degree days 2019 Growing degree days 2020

—Rainfall sum 2019

(a)

A. rugosa 'After Eight'

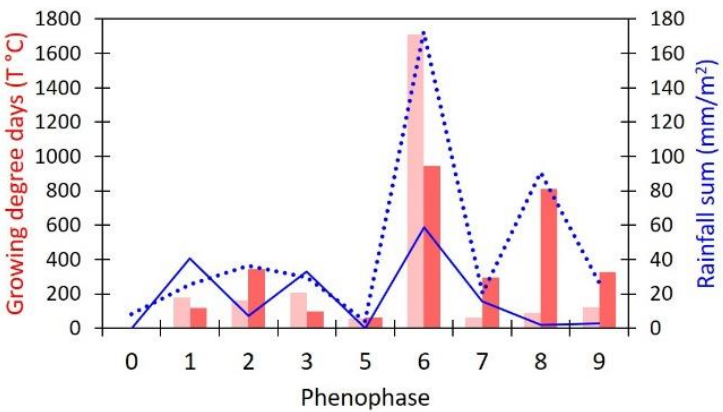

Growing degree days 2019 Growing degree days 2020 —_Rainfall sum 2019 ..... Rainfall sum 2020

(c)

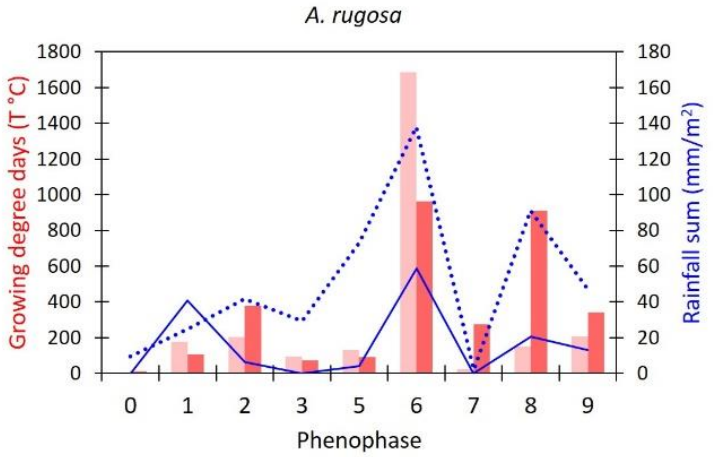

Growing degree days 2019 Growing degree days 2020 — Rainfall sum 2019

-.... Rainfall sum 2020

(b)

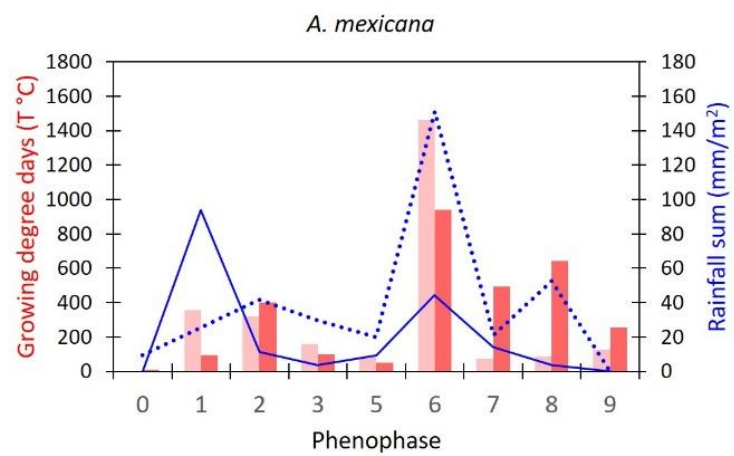

Growing degree days 2019 Growing degree days 2020 —Rainfall sum $2019 \quad$ …. Rainfall sum 2020

(d)

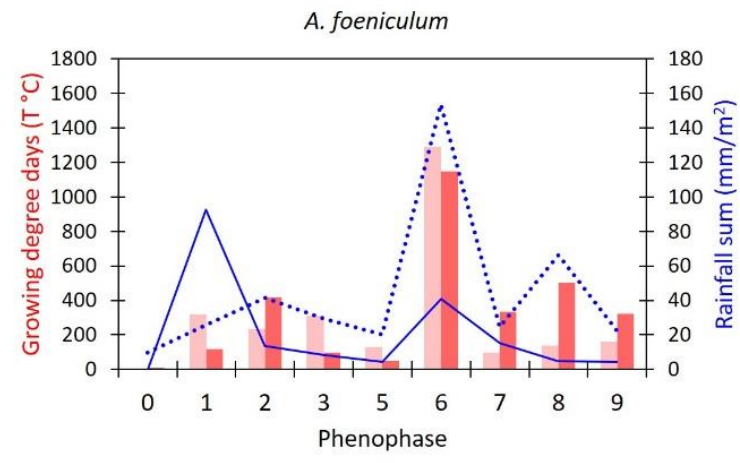

Growing degree days 2019 Growing degree days 2020

_ Rainfall sum 2019

(e)

Figure 7. Growing degree days and rainfall sum per phenophase (BBCH 0-9) in Agastache (a-e) in Cluj-Napoca.

The absence of extreme temperatures ensured that the variations remained within the tolerance limits and did not induce thermic stress to the plants. By comparison, for the sum of precipitations per phenophase, there were noticeable differences between the two years (Figure 7). Interventions such as watering are necessary in conditions of cultivation to prevent the negative influence on biomass. In the year 2020, rainy weather prolonged and slowed down the vegetative development in the first phenophases (stages 2-3) and then, it determined a shortening of the flowering (stage 6) in favor of prolonged fruit development and maturation (stages 7-8).

In 2019, the dispersal of the fruits debuted around the start of October and continued when the vegetation period ended (stage 9). During this period, there was little precipita- 
tion. Compared to the first year, in 2020 the fruit dispersal started earlier, and by the end of September, most fruits were dispersed (Table 5, Figure 7).

Differences between the length of phenophases from the two experimental years may also be attributed in part to the fact that in the first year, the plants started from seed, while in the second-year, plants were already established in the field. It was assumed that in the first year, the share of phenophases was influenced by climatic conditions, characterized by high temperatures and little rainfall. Moderate temperatures were recorded only in phenophase 7, but in this phenophase the precipitations were low (Figure 7).

Regarding GDD accumulated during the vegetation period, these ranged between 2883.2 degrees registered by A. mexicana and 3043.8 degrees by A. rugosa. The precipitations registered in 2020 were more consistent compared to the first year, ranging between 326.97 and $473.24 \mathrm{~mm}$ (Table 5, Figure 7).

According to perennial lifestyle, in the first year, plants had to allocate resources to the formation of vegetative organs to ensure survival over the winter. The longer duration of flowering in the first year could also be attributed to tardy development. A stronger relationship was identified between the GDD per phenophase and the duration of the phenophase than between the sum of precipitations registered per phenophase and the phenophase duration (Figure 8).

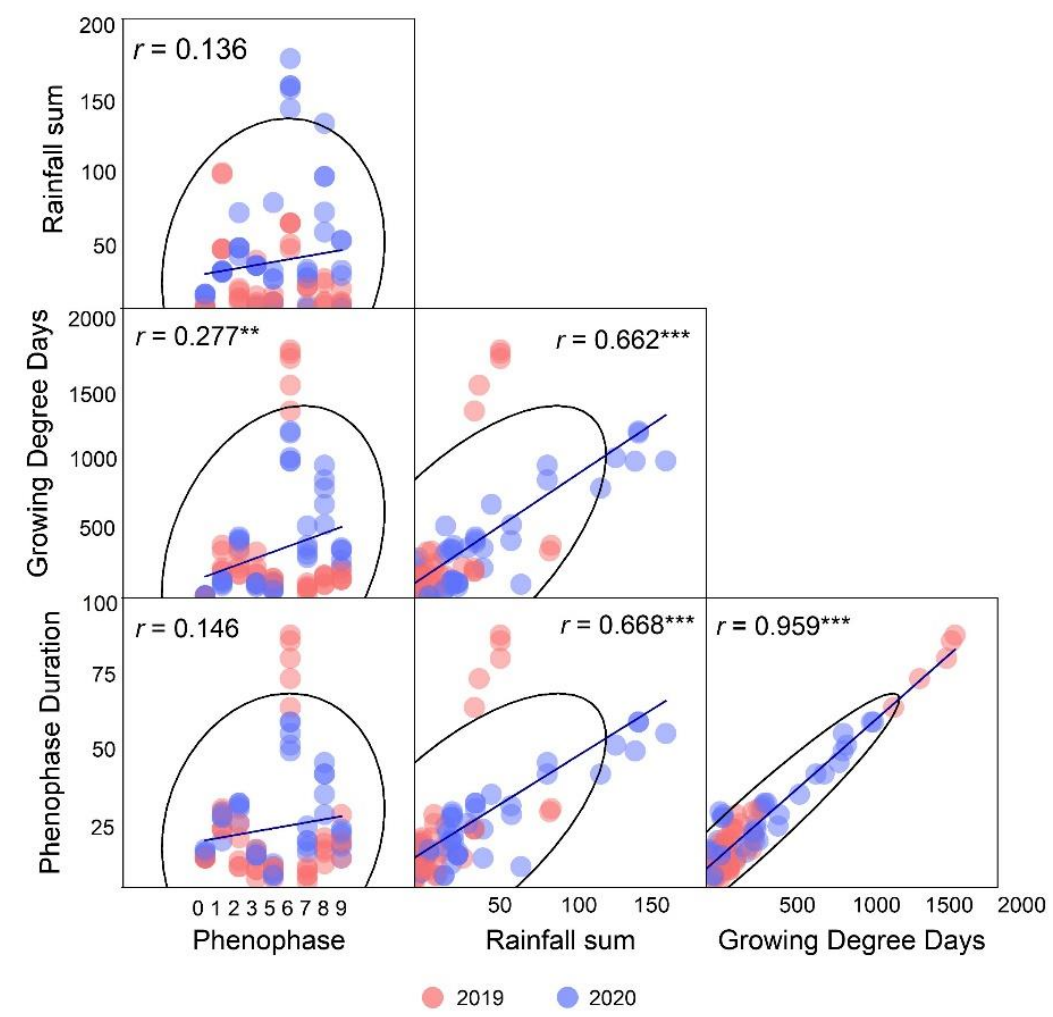

Figure 8. Scatter matrix for the experimental variables in Agastache; ellipse represents 95\% confidence interval (CI); Pearson correlation significant at $p 0.01\left(^{* *}\right)$ and $\left.p 0.001{ }^{* * *}\right)$.

The linear fitting model further confirmed that phenophase duration was to a great extent influenced by GDD (Figure 9). 


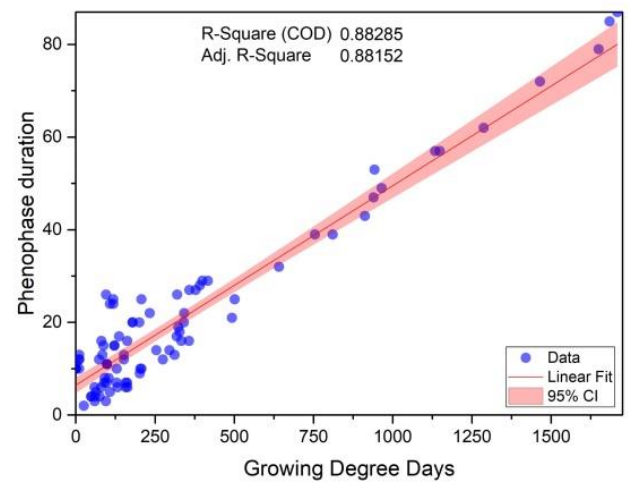

(a)

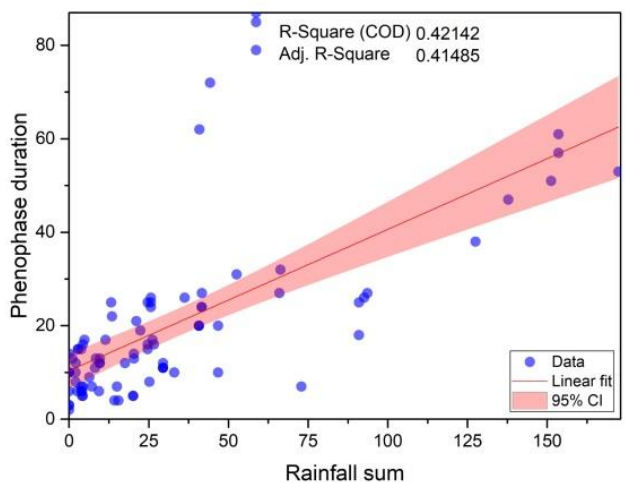

(b)

Figure 9. Linear fitting model for Agastache: (a) relationship between phenophase duration and growing degree days; (b) relationship between phenophase duration and rainfall sum per phenophase; for the regression coefficient, the phenophase duration is the dependent variable; COD—coefficient of determination, Adj.-adjusted.

\section{Discussion}

Choosing genotypes highly compatible with the growing environment is an important condition for ensuring high quantity and quality of raw material from medicinal plants. Concerns regarding the implications of predicted climatic trends on medicinal plants have been expressed in recent literature [42-45] and based on such reports one can infer that cultivation might be a more sustainable way of obtaining them than harvesting from wild flora, as natural ecosystems become more susceptible to the reduction of biodiversity and cascading impacts.

Because phenology changes are the first observable shifts in response to changing climatic conditions [46-48], this subject becomes more relevant than ever, including for cultivated plants. Thus, understating phenology and its conditioning relationship with ecological factors become keys for the successful cultivation of most plant species.

Revived interest in applicative nature of plant phenology is evidenced by new works on phenological description based on standardized BBCH growth stages for various other herbaceous plants, such as stevia (Stevia rebaudiana) [49], yam bean (Pachyrhizus erosus) [50], ginseng (Panax ginseng) [51], chia (Slavia hispanica) [52], lulo (Solanum quitoense var. septentrionale) [53], Gaúcho tomato (Lycopersicum esculentum) [54], chilli (Capsicum annuum, C. chinense, C. baccatum) [55], Jerusalem artichoke (Helianthus tuberosus) [56], Proso millet (Panicum miliaceum) [57], the weed green foxtail (Setaria viridis) [58] and Mediterranean forage legumes [59].

Studies on the cultivation of Agastache species outside their native range [26,41,60,61] or investigation of domestication gradients in their centers of origin [24] are necessary efforts for elucidating possibilities to extend and optimize their cultivation. Cultivation relies on understanding plant biology and requirements in regards to ecological factors that can be achieved through studying their phenology.

Following the study of some of the Agastache species in Cluj-Napoca with the purpose of assessing their prospects for successful cultivation, it was determined that all of them have successfully gone through all the stages of growth and development, produced fruits and survived over the winter, thus being suitable for the cultivation in local conditions. The growing period on average was shorter in the first year (168 days) compared to the second year (199 days), but similarly, in conditions from Ukraine, Agastache had a shorter first growth period (up to 130 days) that became longer (up to 159 days) in subsequent years [41].

The life strategy of perennial plants differs from that of annual plants, since these must maintain meristems past their first growing period. These can also start their vegetative period earlier, having already formed the root system in early spring [62]. In this study, the 
start of vegetative growth stages took place earlier in the second year after planting. This might indicate a good adaptability of the studied species.

Although the four species studied come from different geographical regions regarding the latitudinal limits and distribution on the continents (North America, Asia) (Table 1), still the results obtained indicate a similarity in their behavior (Table S3). A. mexicana with a native distribution more southern compared to other species (a subtropical region of Mexico) behaved similarly with the other more northern species, even in the second year after overwintering in Cluj conditions. However, in the first year, there were some differences for species A. rugosa and the cultivar A. rugosa 'After Eight', as well as for $A$. scrophulariifolia that registered a prolonged share of flowering compared to A. mexicana and A. foeniculum (Figure 6). In the case of A. foeniculum, although this is the species with the most northern distribution limit in North America [20], which implies a higher adaptability to the temperate climate, and being the only species cultivated in Romania until the present time, our results indicate that the share of flowering was the shortest compared to the other species in the first experimental year. In the second year, these differences disappeared (Figure 6). This suggests that although there was a slower adaptation in the first year, in the second year, $A$. foeniculum stabilizes, having a similar performance to the other species, confirming the adaptability of this species once it becomes established. A. scrophulariifolia has a smaller native range than A. foeniculum and is cited as more sensitive to competition from other plants [21]. In spite of this, our results suggest a behavior similar to $A$. rugosa, including the cultivar A. rugosa 'After Eight' — a genotype that was created for long flowering duration.

The maturity of the fruit lasted until the beginning of October, similarly to previous reports in local conditions [26]. In Middle Urals (Russia), the duration of fruit maturation of Agastache spp. lasted from the end of August until October, much longer than the average registered in conditions of Transylvania (Romania) in both experimental years. For the species $A$. foeniculum and $A$. rugosa, the sprouting in the second year was delayed in conditions from Middle Urals, while for A. scrophulariifolia and A. mexicana, the renewal buds did not survive over winter [60]. By comparison, in Romania, the studied species behaved as perennials, all plants forming renewals buds at the base of the stem and surviving over winter, with sprouting occurring in all plants the following spring.

In this study, the average GDD accumulated during the vegetation period (over $10^{\circ} \mathrm{C}$ ) ranged from 2589 to $3151{ }^{\circ} \mathrm{C}$. The values overall in the two years were comparable with those registered in the Transcarpathian region of Ukraine, where the sum of active temperatures above $10^{\circ} \mathrm{C}$ exceeded $3000^{\circ} \mathrm{C}$ and this was considered as appropriate for adequate growth of Agastache [41].

In cultivation, growers have to take measures to mitigate or prevent abiotic stress in plants that might negatively impact their growth. In this regard, for the cultivation of these species, it is important to take into consideration the necessary care during critical stages when plants might be more sensitive to a lack of moisture in the substrate/soil. Such stages are: germination, post-transfer of seedlings in the field, initial vegetative growth (stages 1-3) and reproductive period (stages 5-7). In order to cultivate these species, the quality of the seeds, the vigor of the seedlings and the planting period can also be considered essential, having an impact on the subsequent growth stages [63] and on the biomass. Similar to other crops, their management must be done with maximum responsibility. Due to the small size of the nutlets used for generative propagation, the culture is best established through seedlings. For a good germination capacity, the seeds must be harvested from mature plants and sown in controlled conditions during March.

Flowering is a crucial event in plant growth and development; flowering phenology affects seed size, fruit or seed spread, pollinator abundance [64-66], but also the optimal time to harvest Agastache species for valorization purposes. For all the studied species, the dominant phenophase during the growth period was the flowering. A phenological study on several species of Agastache in conditions from Ekaterinburg (Russia), reported a flowering duration of 40-60 days [60], a shorter duration compared to the average obtained 
in the current study. However, one has to notice that Ekaterinburg is more northern compared to Cluj-Napoca.

The fact that these species have a long flowering duration is beneficial for better managing the time of harvest. Under field cultivation, plants of this genus were reported to produce an amount of fresh biomass of $14.5 \mathrm{t} / \mathrm{ha}$ in conditions of Transcarpathia, Ukraine [41] and 3.05-3.83 t/ha of dry biomass in conditions of Transylvania, Romania [26].

The results suggested a highly significant relationship between phenophase duration and GDD. A study conducted in a temperate climate (Sweden) found that cumulative models based on meteorological measurements (such as the sum of temperatures) are precise predictors of flowering of some herbaceous species [67]. Flowering is also dependent on the growth stage because it occurs when the plant has reached its characteristic size or has undergone a certain stage of development, although this usually depends on a cumulative heat sum [67].

In conditions from Cluj-Napoca, Agastache flowering took place during the summer months, when it is usually warm, and with a deficit of precipitation due to climatic particularities. During this period, it is necessary to intervene with watering, especially since in this phenophase the raw material (herba) is harvested for therapeutic purposes.

The effect of water deficit events on phenology and yield may depend on timing and occurrence during the vegetation phases. Phenological responses to water deficiency often have an effect on plant reproductive stages [68]. Temperature can indirectly affect the availability of nutrients by changing soil moisture or the supply of organic matter in the soil. It has been suggested that temperature changes and precipitation associated with global changes could have a greater impact on plant growth and productivity than the direct effects of increased $\mathrm{CO}_{2}$ [69]. Unfortunately, changes in temperature and precipitation are more difficult to predict and can be very site-specific. Water availability is likely to change in many regions, as rainfall increases in some areas and decreases in others [70].

The vegetation period for the studied species ended in September-October. Based on this study, it is suggested that in local conditions, the species A. rugosa and A. foeniculum are the tardiest, while the others have a somewhat similar length of vegetation periods. Senescence onset of aboveground parts occurred in autumn starting with September and progressing until or throughout October. Leaf senescence in perennials is in close relationship with the dormancy of those organs that survive unfavorable periods [71]. At the onset of leaf senescence, the nutrients are redistributed to be stored in other plant parts [72,73]. It was proposed that photoperiod manifests a strict control on leaf senesce at latitudes where winters are severe, while the temperature gains importance as winters become less severe [74], since leaf senescence is an evolutionary acquired developmental strategy, there is a specificity according to environments these evolved in [74,75].

Based on this study, it can be asserted that phenology is a useful indicator, easy to determine and has practical applications in agronomy. Following the comparative study of the Agastache sp. during two experimental years, some differences were observed in terms of growth stages and development, their behavior, vegetation period and succession of phenophases that can help the growers in elaborating the agronomic calendar for this crop and also can be used to optimize the cultivation technology for given species in local conditions.

\section{Conclusions}

This paper provides a standardization and comprehensive phenological description for Agastache based on the BBCH scale, as observed for some species cultivated in field conditions under temperate continental climate from Cluj-Napoca, Transylvania. It was determined that in local conditions the studied species (A. scrophulariifolia, A. mexicana, A. foeniculum, A. rugosa and A. rugosa 'After Eight') behaved as hardy perennials in the studied years, with a hemicryptophyte lifestyle characterized by alternation of growth and resting period. During the vegetation period, nine growth stages were identified: germination/emergence, leaf development, formation of side shoots, stem elongation, 
inflorescence emergence, flowering, fruit development, fruit maturity, senescence and beginning of resting. The critical stages are: germination, post-transfer of seedlings in the field, initial vegetative growth (stages 1-3) and reproductive period (stages 5-7). Following the study of Agastache in Cluj-Napoca with the purpose of assessing their prospects for successful cultivation was determined that all species had a complete life cycle, produced fruits and survived over winter, thus being suitable for cultivation locally. There were no plant losses between the two years, and all plants overwintered successfully, suggesting these are hardy in the local climate. The growth period in the first year after planting in the field lasted $168 \pm 3.51$ days (2019) with a range of 20 days. The second growth period lasted $199 \pm 1.82$ days (2020) with a range of 10 days. This indicates acclimatization of the species in the local conditions. For all species studied during both growing periods, the flowering was the dominant stage lasting between 47 and 87 days. The long duration of the blooming phase is highly beneficial for ornamental purposes and honey production, while herba harvesting can be managed better. Flowering duration was shortened by rainy weather, in favor of lengthening of fruit development and maturation. There was a highly significant relationship identified between the phenophase duration and growing degree days $\left(R^{2}=0.882, r=0.959\right)$. With the purpose of diversifying the range of cultivated medicinal plants, the Agastache species studied can be taken into consideration for cultivation at least in the region of Transylvania, for ensuring raw materials for the pharmaceutical industry. Due to the small size of the tetra-nutlets, it is recommended to establish the crop through seedlings_-similar to other species from the family Lamiaceae (mint, basil, sage). The $\mathrm{BBCH}$ scale is a useful instrument in agronomy for determining the suitability for cultivation in new areas of given species with promising valorization potential, due to immediate application in: optimizing cultivation technology, plant breeding, establishing the calendar of agronomic activities and determining critical stages during plant growth that require interventions from growers (such as irrigation) - all these in order to ensure high biomass production and successful cultivation.

Supplementary Materials: The following are available online at https://www.mdpi.com/article/ 10.3390/agronomy11112280/s1, Table S1: Growing degree days $\left({ }^{\circ} \mathrm{C}\right)$ 2019-2020; Table S2: Sum of rainfall per phenophase (mm) 2019-2020; Table S3: Proportion of phenophase (\%) from the vegetative period 2019-2020.

Author Contributions: Conceptualization, R.V. and D.V.; methodology, R.V.; formal analysis, R.V.; investigation, R.V.; resources, R.V.; data curation, R.V. and A.S.; writing-original draft preparation, R.V., A.O., A.S. and I.C.; writing—review and editing, R.V., A.O., A.S., D.V. and I.C.; visualization, I.C.; supervision, R.V. All authors have read and agreed to the published version of the manuscript.

Funding: This research received no external funding.

Data Availability Statement: Not applicable.

Conflicts of Interest: The authors declare no conflict of interest.

\section{References}

1. Lubbe, A.; Verpoorte, R. Cultivation of Medicinal and Aromatic Plants for Specialty Industrial Materials. Ind. Crops Prod. 2011, 34, 785-801. [CrossRef]

2. Argyropoulos, D. EIP-AGRI Focus Group Plant-Based Medicinal and Cosmetic Products 2019. Available online: https://ec. europa.eu/eip/agriculture/sites/default/files/fg35_starting_paper_2019_en.pdf (accessed on 9 September 2021).

3. Lint, H.; Epling, C. A Revision of Agastache. Am. Midl. Nat. 1945, 33, 207-230. [CrossRef]

4. Simpson, M.G. Plant Systematics; Elsevier Academic Press: London, UK, 2006; ISBN 0-12-644460-9.

5. Muntean, L.S.; Cernea, S.; Morar, G.; Duda, M.M.; Vârban, D.I.; Muntean, S.; Moldovan, C. Fitotehnie; Editura Risoprint: Cluj-Napoca, Romania, 2014; ISBN 978-973-53-1273-2.

6. Carović-Stanko, K.; Petek, M.; Grdiša, M.; Pintar, J.; Bedeković, D.; Herak Ćustić, M.; Satovic, Z. Medicinal Plants of the Family Lamiaceae as Functional Foods-A Review. Czech J. Food Sci. 2016, 34, 377-390. [CrossRef]

7. WFO. Agastache J. Clayton Ex Gronov. Available online: http://www.worldfloraonline.org/taxon/wfo-4000000903 (accessed on 12 September 2021).

8. Lord, T. Flora: The Gardener's Bible; Cassell—Weidenfeld \& Nicolson: London, UK, 2003. 
9. Vogelmann, J.E. Crossing Relationships among North American and Eastern Asian Populations of Agastache Sect. Agastache (Labiatae). Syst. Bot. 1985, 10, 445-452. [CrossRef]

10. Zielińska, S.; Matkowski, A. Phytochemistry and Bioactivity of Aromatic and Medicinal Plants from the Genus Agastache (Lamiaceae). Phytochem. Rev. 2014, 13, 391-416. [CrossRef]

11. Quattrocchi, U. CRC World Dictionary of Medicinal and Poisonous Plants: Common Names, Scientific Names, Eponyms, Synonyms, and Etymology (5 Volume Set); CRC Press: Boca Raton, FL, USA, 2016; ISBN 978-1-4822-5064-0.

12. Fuentes-Granados, R.; Widrlechner, M.; Wilson, L. An Overview of Agastache Research. J. Herbs Spices Med. Plants 1998, 6, 69-97. [CrossRef]

13. Najar, B.; Marchioni, I.; Ruffoni, B.; Copetta, A.; Pistelli, L.; Pistelli, L. Volatilomic Analysis of Four Edible Flowers from Agastache Genus. Molecules 2019, 24, 4480. [CrossRef]

14. Anand, S.; Pang, E.; Livanos, G.; Mantri, N. Characterization of Physico-Chemical Properties and Antioxidant Capacities of Bioactive Honey Produced from Australian Grown Agastache Rugosa and Its Correlation with Colour and Poly-Phenol Content. Molecules 2018, 23, 108. [CrossRef]

15. Anand, S.; Deighton, M.; Livanos, G.; Pang, E.C.K.; Mantri, N. Agastache Honey Has Superior Antifungal Activity in Comparison with Important Commercial Honeys. Sci. Rep. 2019, 9, 18197. [CrossRef]

16. Anand, S.; Deighton, M.; Livanos, G.; Morrison, P.D.; Pang, E.C.K.; Mantri, N. Antimicrobial Activity of Agastache Honey and Characterization of Its Bioactive Compounds in Comparison With Important Commercial Honeys. Front. Microbiol. 2019, 10, 263. [CrossRef]

17. Bolesław, J.; Zbigniew, K. Nectar Secretion and Honey Potential of Honey-Plants Growing under Poland's Conditions. Part XII. J. Apic. Sci. 2001, 45, 29-34.

18. Lewis, A. Butterfly Gardens: Luring Nature's Loveliest Pollinators to Your Yard; Brooklyn Botanic Garden: Brooklyn, NY, USA, 2007; ISBN 978-1-889538-32-7.

19. Corrigan, E.E. Agastache Scrophulariifolia; New England Wild Flower Society: Framingham, MA, USA, 2002.

20. USDA Plants Database. Available online: https://plants.sc.egov.usda.gov/home/plantProfile?symbol=AGFO (accessed on 24 October 2021).

21. Sheahan, C.M. Fact Sheet for Purple Giant Hyssop (Agastache Scrophulariifolia); USDA-Natural Resources Conservation Service, Cape May Plant Material Center: Cape May, NJ, USA, 2012. Available online: https:/ / plants.usda.gov/DocumentLibrary/factsheet/ pdf/fs_agsc.pdf (accessed on 9 September 2021).

22. Kang, M.J.; Sundan, S.; Lee, G.A.; Ko, H.C.; Chung, J.W.; Huh, Y.C.; Gwag, J.G.; Oh, S.J.; Kim, Y.G.; Cho, G.T. Genetic Diversity and Population Structure of Korean Mint Agastache Rugosa (Fisch \& Meyer) Kuntze (Lamiaceae) Using ISSR Markers. Korean J. Plant Resour. 2013, 26, 362-369. [CrossRef]

23. World Health Organization; Regional Office for the Western Pacific. Medicinal Plants in the Republic of Korea: Information on 150 Commonly Used Medicinal Plants; WHO Regional Office for the Western Pacific: Manila, Philippines, 1998; ISBN 978-92-9061-120-2.

24. Carrillo-Galván, G.; Bye, R.; Eguiarte, L.E.; Cristians, S.; Pérez-López, P.; Vergara-Silva, F.; Luna-Cavazos, M. Domestication of Aromatic Medicinal Plants in Mexico: Agastache (Lamiaceae)-an Ethnobotanical, Morpho-Physiological, and Phytochemical Analysis. J. Ethnobiol. Ethnomed. 2020, 16, 22. [CrossRef] [PubMed]

25. Palma-Tenango, M.; Sánchez-Fernández, R.E.; Soto-Hernández, M. A Systematic Approach to Agastache Mexicana Research: Biology, Agronomy, Phytochemistry, and Bioactivity. Molecules 2021, 26, 3751. [CrossRef] [PubMed]

26. Duda, M.; Matei, C.I.; Vârban, D.I.; Muntean, S.; Moldovan, C. The Results of Cultivating the Species Agastache Foeniculum (Pursh) Kuntze at Jucu, CJ. Bull. Univ. Agric. Sci. Vet. Med. Cluj Napoca Agric. 2013, 70, 214-217. [CrossRef]

27. Vânătoru, C.; Zamfir, B.; Bratu, C.; Peticila, A. Lophanthus Anisatus, a Multi-Purpose Plant, Acclimatized and Improved at VRDS Buzau. Sci. Pap. Ser. B Hortic. 2015, 59, 277-280.

28. Meier, U. Growth Stages of Mono- and Dicotyledonous Plants: BBCH Monograph; Julius Kühn-Institut: Quedlinburg, Germany, 2018; Available online: https://www.julius-kuehn.de/media/Veroeffentlichungen/bbch\%20epaper\%20en/page.pdf (accessed on 9 September 2021). [CrossRef]

29. Meier, U.; Bleiholder, H.; Buhr, L.; Feller, C.; Hack, H.; Heß, M.; Lancashire, P.D.; Schnock, U.; Stauß, R.; Van Den Boom, T.; et al. The BBCH System to Coding the Phenological Growth Stages of Plants-History and Publications. J. Cultiv. Plants 2009, 61, 41-52. [CrossRef]

30. Bleiholder, H.; van den Boom, T.; Stauss, R. A uniform code for the growth stages of crops and weeds. Gesunde Pflanz. Ger. FR 1989, 41, 381-384.

31. Index Seminum - Hortus Agro-Botanicus Napocensis; Academic Pres: Cluj-Napoca, Romania, 2021; ISSN $1223-6055$.

32. Crișan, I.; Vidican, R.; Olar, L.; Stoian, V.; Morea, A.; Ștefan, R. Screening for Changes on Iris Germanica L. Rhizomes Following Inoculation with Arbuscular Mycorrhiza Using Fourier Transform Infrared Spectroscopy. Agronomy 2019, 9, 815. [CrossRef]

33. Criveanu, H. Agrometeorology; Risoprint: Cluj-Napoca, Romania, 2021; ISBN 973-656-135-6.

34. Climate Cluj: Temperature, Climate Graph, Climate Table for Cluj-Climate-Data.Org. Available online: https:/ / en.climate-data. org/europe/romania/cluj-511/ (accessed on 23 October 2021).

35. Kabbes, B. Agastache Plant Named 'After Eight'. U.S. Patent USPP15921P2, 16 August 2005. Available online: https://patents. google.com/patent/USPP15921P2/en (accessed on 10 November 2021).

36. Ion, V. Fitotehnie; USAMV: Bucharest, Romania, 2010. 
37. Bîlteanu, G.; Fazekaș, I.; Salontai, A.; Bîrnaure, V.; Ciobanu, F.; Vasilică, C. Fitotehnie; Didactică și Pedagogică: Bucharest, Romania, 1979.

38. Bîlteanu, G.; Bîrnaure, V.; Miclea, E.; Bălașa, M.; Negrilă, A.; Oprea, D.D. Memorator Pentru Producția Vegetală; Ceres: Bucharest, Romania, 1974.

39. XLSTAT I Statistical Software for Excel. Available online: https://www.xlstat.com/en/ (accessed on 1 September 2021).

40. OriginLab-Origin and OriginPro-Data Analysis and Graphing Software. Available online: https://www.originlab.com/ (accessed on 9 September 2021).

41. Svitlana, K.; Vladimir, V.; Inna, M. Perspectives Culture of the Lophanthus Anisatus Benth. and Peculiarities of Its Ontogenesis in the Conditions of the Lowland Zone of Transcarpathian. Ecol. Evol. Biol. 2020, 5, 29. [CrossRef]

42. Gairola, S.; Shariff, N.M.; Bhatt, A.; Kala, C.P. Influence of Climate Change on Production of Secondary Chemicals in High Altitude Medicinal Plants: Issues Needs Immediate Attention. J. Med. Plants Res. 2010, 4, 1825-1829. [CrossRef]

43. Sharma, M.; Thakur, R.; Sharma, M.; Sharma, A.K.; Sharma, A.K. Changing Scenario of Medicinal Plants Diversity in Relation to Climate Chnage. Plant Arch. 2020, 20, 4389-4400.

44. Applequist, W.L.; Brinckmann, J.A.; Cunningham, A.B.; Hart, R.E.; Heinrich, M.; Katerere, D.R.; van Andel, T. Scientists' Warning on Climate Change and Medicinal Plants. Planta Med. 2020, 86, 10-18. [CrossRef] [PubMed]

45. Das, M.; Jain, V.; Malhotra, S.K. Impact of Climate Change on Medicinal and Aromatic Plants: Review. Indian J. Agric. Sci. 2016, $86,1375-1382$.

46. Menzel, A.; Yuan, Y.; Matiu, M.; Sparks, T.; Scheifinger, H.; Gehrig, R.; Estrella, N. Climate Change Fingerprints in Recent European Plant Phenology. Glob. Change Biol. 2020, 26, 2599-2612. [CrossRef] [PubMed]

47. Fu, Y.; Li, X.; Zhou, X.; Geng, X.; Guo, Y.; Zhang, Y. Progress in Plant Phenology Modeling under Global Climate Change. Sci. China Earth Sci. 2020, 63, 1237-1247. [CrossRef]

48. Rosbakh, S.; Hartig, F.; Sandanov, D.V.; Bukharova, E.V.; Miller, T.K.; Primack, R.B. Siberian Plants Shift Their Phenology in Response to Climate Change. Glob. Change Biol. 2021, 27, 4435-4448. [CrossRef]

49. Le Bihan, Z.; Cosson, P.; Rolin, D.; Schurdi-Levraud, V. Phenological Growth Stages of Stevia (Stevia Rebaudiana Bertoni) According to the Biologische Bundesanstalt Bundessortenamt and Chemical Industry (BBCH) Scale. Ann. Appl. Biol. 2020, 177, 404-416. [CrossRef]

50. Pati, K.; Kaliyappan, R.; Chauhan, V.B.S.; Bansode, V.; Nedunchezhiyan, M.; Hegde, V.; Koundinya, A.V.V. Phenological Growth Stages of Underutilised Crop Yam Bean (Pachyrhizus Erosus L. Urban) According to the Extended BBCH Scale. Ann. Appl. Biol. 2020, 177, 417-423. [CrossRef]

51. Kim, Y.-S.; Park, C.-S.; Lee, D.-Y.; Lee, J.-S.; Lee, S.-H.; In, J.-G.; Hong, T.-K. Phenological Growth Stages of Korean Ginseng (Panax Ginseng) According to the Extended BBCH Scale. J. Ginseng Res. 2021, 45, 527-534. [CrossRef]

52. Brandán, J.P.; Curti, R.N.; Acreche, M.M. Phenological Growth Stages in Chia (Salvia Hispanica L.) According to the BBCH Scale. Sci. Hortic. 2019, 255, 292-297. [CrossRef]

53. Ramírez, F.; Davenport, T.L. The Development of Lulo Plants (Solanum Quitoense Lam. Var. Septentrionale) Characterized by BBCH and Landmark Phenological Scales. Int. J. Fruit Sci. 2020, 20, 562-585. [CrossRef]

54. Cardoso, E.F.; Lopes, A.R.; Dotto, M.; Pirola, K.; Giarola, C.M. Phenological growth stages of Gaúcho tomato based on the BBCH scale. Comun. Sci. 2021, 12, e3490. [CrossRef]

55. Feldmann, F.; Rutikanga, A. Phenological Growth Stages and BBCH-Identification Keys of Chilli (Capsicum Annuum L., Capsicum Chinense JACQ., Capsicum Baccatum L.). J. Plant Dis. Prot. 2021, 128, 549-555. [CrossRef]

56. Kliszcz, A. Phenological Growth Stages and BBCH-Identification Keys of Jerusalem Artichoke (Helianthus Tuberosus L.). Ann. Univ. Paedagog. Crac. Stud. Nat. 2021, 6. Available online: https://aupcstudianaturae.up.krakow.pl/article/view/8420 (accessed on 10 November 2021).

57. Ventura, F.; Vignudelli, M.; Poggi, G.M.; Negri, L.; Dinelli, G. Phenological Stages of Proso Millet (Panicum Miliaceum L.) Encoded in BBCH Scale. Int. J. Biometeorol. 2020, 64, 1167-1181. [CrossRef]

58. Junqueira, N.E.G.; Bezerra, A.C.M.; Cattem, M.V.O.; Medici, L.O.; Alves-Ferreira, M.; Macrae, A.; Ortiz-Silva, B.; Reinert, F. Phenology of the Genetic Model Setaria Viridis (Poaceae) According to the BBCH-Scale of Development. Bot. J. Linn. Soc. 2020, 192, 224-241. [CrossRef]

59. Enriquez-Hidalgo, D.; Cruz, T.; Teixeira, D.L.; Steinfort, U. Phenological Stages of Mediterranean Forage Legumes, Based on the BBCH Scale. Ann. Appl. Biol. 2020, 176, 357-368. [CrossRef]

60. Vasfilova, E.; Vorob'eva, T. Little-Known Medicinal Plants with a Widespectrum of Pharmacological Action under the Conditions of Introduction in the Middle Urals. BIO Web Conf. 2020, 24, 00090. [CrossRef]

61. Rudik, G. Ontomorphogenesis of Agastache Rugosa (Fisch. et C.A. Mey.) O. Kuntze Ex Situ. Mod. Phytomorphol. 2013, 4, 257-260. [CrossRef]

62. Lundgren, M.R.; Des Marais, D.L. Life History Variation as a Model for Understanding Trade-Offs in Plant-Environment Interactions. Curr. Biol. 2020, 30, R180-R189. [CrossRef] [PubMed]

63. Silva, H.; Arriagada, C.; Campos-Saez, S.; Baginsky, C.; Castellaro-Galdames, G.; Morales-Salinas, L. Effect of Sowing Date and Water Availability on Growth of Plants of Chia (Salvia Hispanica L.) Established in Chile. PLoS ONE 2018, 13, e0203116. [CrossRef] [PubMed] 
64. Bolmgren, K.; Cowan, P.D. Time-Size Tradeoffs: A Phylogenetic Comparative Study of Flowering Time, Plant Height and Seed Mass in a North-Temperate Flora. Oikos 2008, 117, 424-429. [CrossRef]

65. Du, G.; Qi, W. Trade-Offs between Flowering Time, Plant Height, and Seed Size within and across 11 Communities of a QingHai-Tibetan Flora. Plant Ecol. 2010, 209, 321-333. [CrossRef]

66. Forrest, J.; Inouye, D.W.; Thomson, J.D. Flowering Phenology in Subalpine Meadows: Does Climate Variation Influence Community Co-Flowering Patterns? Ecology 2010, 91, 431-440. [CrossRef]

67. Diekmann, M. Relationship between Flowering Phenology of Perennial Herbs and Meteorological Data in Deciduous Forests of Sweden. Can. J. Bot. 1996, 74, 528-537. [CrossRef]

68. Blum, A. Crop Responses to Drought and the Interpretation of Adaptation. Plant Growth Regul. 1996, 20, 135-148. [CrossRef]

69. Körner, C. Plant CO2 Responses: An Issue of Definition, Time and Resource Supply. New Phytol. 2006, 172, 393-411. [CrossRef]

70. Christensen, J.H.; Christensen, O.B. A Summary of the PRUDENCE Model Projections of Changes in European Climate by the End of This Century. Clim. Chang. 2007, 81,7-30. [CrossRef]

71. Forbes, J.C.; Watson, R.D. Plants in Agriculture; Cambridge University Press: Cambridge, UK, 1999; ISBN 0-521-42791-6.

72. Aerts, R. Nutrient Resorption from Senescing Leaves of Perennials: Are There General Patterns? J. Ecol. 1996, 84, 597-608. [CrossRef]

73. Brant, A.N.; Chen, H.Y.H. Patterns and Mechanisms of Nutrient Resorption in Plants. Crit. Rev. Plant Sci. 2015, 34, 471-486. [CrossRef]

74. Estiarte, M.; Peñuelas, J. Alteration of the Phenology of Leaf Senescence and Fall in Winter Deciduous Species by Climate Change: Effects on Nutrient Proficiency. Glob. Chang. Biol. 2015, 21, 1005-1017. [CrossRef] [PubMed]

75. Crişan, I.; Stoie, A.; Cantor, M. Overwintering of Some Hardy Iris Species in Agro-Botanical Garden UASVM Cluj-Napoca. Agricultura 2016, 99, 6-14. [CrossRef] 